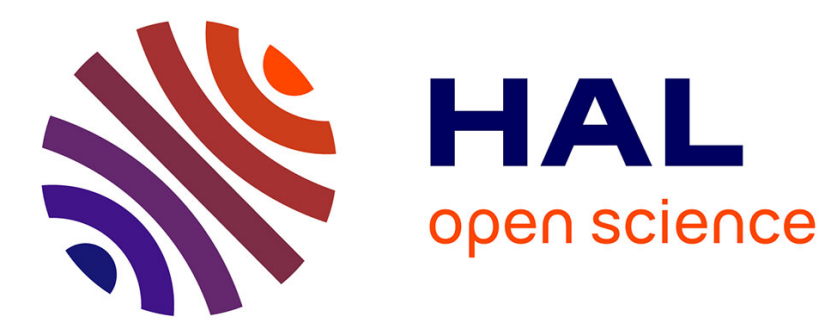

\title{
GENDER AND CENTRAL BANKING
}

Ibrahima Diouf, Dominique Pépin

\section{To cite this version:}

Ibrahima Diouf, Dominique Pépin. GENDER AND CENTRAL BANKING. Economic Modelling, 2017, 61, pp.193-206. 10.1016/j.econmod.2016.12.006 . hal-01224266v3

\section{HAL Id: hal-01224266 \\ https://hal.science/hal-01224266v3}

Submitted on 12 Apr 2017

HAL is a multi-disciplinary open access archive for the deposit and dissemination of scientific research documents, whether they are published or not. The documents may come from teaching and research institutions in France or abroad, or from public or private research centers.
L'archive ouverte pluridisciplinaire HAL, est destinée au dépôt et à la diffusion de documents scientifiques de niveau recherche, publiés ou non, émanant des établissements d'enseignement et de recherche français ou étrangers, des laboratoires publics ou privés. 


\title{
Gender and Central Banking
}

\author{
Ibrahima Diouf, Dominique Pépin
}

\begin{abstract}
Female Central Bank chairs represent but a tiny minority. To understand why, this article analyzes socio-economic and socio-political characteristics of the countries where women have chaired Central Banks. Then, it suggests that gender differences in preferences as regards monetary policy goals may have some influence. An innovative econometric methodology, which does not require estimating all the structural and preference parameters of a monetary model, but only how men and women's parameters differ, is developed to test this hypothesis. The results show that female Central Bank chairs focus more than their male counterparts on achieving the price stability goal. This means, then, that women are more resistant than men to political pressures. Finally, it concludes that gender differences in degree of conservatism may be an explanatory factor in female underrepresentation in the Central Bank chairs.
\end{abstract}

Keywords: Central Bank, conservatism, female, gender gap, monetary policy, preference parameters.

JEL Codes: E52, E58, J16, Z10

\section{Introduction}

«Mr. Summers and Mr. Yellen... euh, Ms. Yellen ».

This slip of the tongue by President Obama speaks volumes about women's absence in the world of central bankers (Perlberg, 2013).

As known, Central Banks are among the largest institutions in modern economies. In charge of defining and implementing of monetary policy, they determine the stock of money in circulation, set the level of short rates and perform the essential public functions (management of foreign exchange reserves, banking supervision). Central Bankers' actions have an immense impact on the functioning of our economy. But, until recently, women were deeply underrepresented in Central Banks. It seems that women have greater access to positions of responsibility in politics than in Central Banks where the glass ceiling is tougher. For instance, in Europe, among the 23-member policy board and the six-member Executive Board 
of the European Central Bank (ECB), there are no women at all. Since its creation, the ECB's Executive Board has included only two.

The literature has just begun to worry about women's absence in monetary policy making (Chappell and McGregor, 2000). Most of the existing studies focus on the composition of the Monetary Policy Committees (MPC). They are related to the Federal Open Market Committee (FOMC) of the US Federal Reserve and the Board of the European Central Bank (ECB). The main idea is that the diversity in the MPC, in terms of gender, but also of age, of professional, sectoral and academic backgrounds, can influence the monetary policy decisions (Farvaque et al., 2014, Masciandaro et al., 2016). In particular, it points out that women's presence in the MPC could have an important effect on policy outcomes (Chappell et al., 2005; Farvaque et al., 2011; Bennani et al., 2015; Masciandaro et al., 2016). The findings obtained by the empirical literature highlighted a higher share of women in the MPC is associated positively with price stability.

In others words, in their decisions, female monetary policymakers are rather inclined to fight against inflation. To explain this attitude, it is observed that, from some level of responsibility, women seek to prove that they can be tougher than men. In particular, as central bankers, they need to make or to acquire a reputation and credibility. Hence they are invited to have hawkish rather than dovish attitude (Wilson, 2014; Hix et al., 2010; Farvaque et al., 2011, 2014; Eijffinger et al., 2015; Masciandaro et al., 2016). Thus, higher women's presence in MPC is associated with better performance in terms of price stability.

In this paper, we try to identify the factors which may explain the absence of females' Central Bank chairs. Indeed, in many countries, women have access to the highest political positions as Head of State, Prime ministers. For instance, in Germany, France, England, Norway, women have been Prime ministers, but, have never been appointed Central Bank chairwoman. Only a minority of women have managed to break the glass ceiling and reached the Central Bank chair. This prestigious function remains monopolized by men.

Nowadays, there is every indication Central Bank chairs are important people. In their duties, they have the mastering of the monetary policy agenda (Riboni and Ruge-Murcia, 2008). This tends to show that they are powerful and influential: powerful, because the Central Bank's independence protect them from all kinds of political pressures; influential, through the credit that markets and governments attribute to their words and the consequences of their decisions on the economy. This is why Ms. Janet Yellen is considered as the second most powerful person after the US President (Gergen, 2013). Her appointment, in 2014, as the 
first female to chair the Federal Reserve Bank, i.e. the world's largest Central Bank, is definitely an essential milestone for female representation in the world of central bankers, i.e. people who actually make monetary policy (Jones, 2013).

So what factors can account for the women's absence as Central Bank chairs? Obviously, there is not one specific factor. Formal or informal barriers are often pointed out, for example:

A) The reluctance of women for economics and finance studies (Hale and Regev, 2001);

B) The women's absence in the closed networks of influence from which Central Bank chairs are chosen.

The first argument is not consistent with the facts. As noted by the website Worldwide Guide to Women in Leadership, between 2000 and 2015, over 200 women headed the Ministry of economy, finance and/or budget in their country or territory. In early 2015, five are still in office, in: East Timor; Lesotho; Republic of Bosnia-Herzegovina; Somaliland; the United Kingdom. Holding these positions requires commitment, availability and skills, at least equal with those of a Central Bank chair.

The second argument is, finally, misleading. That is what appears from J.K. Galbraith's ironic words when he observed "In Central Banks, as in diplomacy, the look, well-cut conventional clothing and an ease to keep company with very rich people counts for a lot with much lower results" (1977, p. 217). However, it should not be excluded from discussion. The idea is that there are differences in preferences for the monetary policy goals (Krause and Méndez, 2008). These differences are explained simply because monetary policy decisions will affect, as the case may be, price levels, economic growth, employment and income with consequences on individual and collective well-being (Epstein and Yeldan, 2010). Hence, the aversion to inflation will change according to individuals or individual generations (Farvaque and Mihailov, 2009, Scheve, 2004). Thus, considering the independence that Central Banks enjoy, governments want someone with preferences compatible with theirs to chair Central Banks. Commercial banks wish to know the Central Bank chair appointed to ensure that the preferences are not in conflict with their own interests.

Indeed, according to the economic theory of bureaucracy, people are driven by self-interest, and appointing them as central banker does not change his nature. In others words, Central Banks' decisions can be politically expensive (Toma and Toma, 1986). Hence, the rational choice(s) made by governments when appointing Central Bank chair with particular profiles (Chang, 2006). This rationality can be extended to commercial banks concerned to preserve 
their interests. In the light of the effects of central bankers' decisions, we assume that the women's absence from Central Bank chairs can be accounted for by their version to inflation.

In this respect, this paper examines female Central Bank chairs' degree of conservatism, as defined by Rogoff (1985), with respect to their male counterparts. For that purpose, an innovative econometric methodology, which does not require estimating all the structural and preference parameters of a monetary model, but only how men and women's parameters differ, is developed to measure the influence of gender's role in central banking. But first, it is worth to note that only a minority of women have managed to break the glass ceiling to reach the chair of the Central Bank.

\section{A minority of female Central Bank chairs}

A close scrutiny of Central Banks' organization charts reveals that they are overwhelmingly chaired by men. The oldest among them, the Swedish Riksbank (founded in 1668), has never been chaired by a female ${ }^{1}$. Since the 1950 s, only 56 women have chaired a Central Bank. In 2015, on a full-time basis, only 16 women chaired a Central Bank out of a total of 184 worldwide i.e. less than $10 \%(8.69 \%)$. Among the 34 Organization for Economic Cooperation and Development (OECD) countries, i.e. economically influential, 27 have never appointed female Central Bank chairs; the seven exceptions are Austria, Denmark, Finland, former East Germany, Israel, Poland and the United States.

By crossing available data in periodicals and newspapers (Central Banking; Financial Times) and several websites (CentralBankNews.info; The Group of Thirty; Council for Parity Democracy; Worldwide Guide to Women in Leadership; www.guide2womenleaders.com; BloombergBusiness; CentralBanking.com; Connecting Women in Sovereign Entities Globally (WSE)), we have identified 56 female chairs, since 1949, for 46 Central Banks ${ }^{2}$. The results obtained are summarized in table 1.

\footnotetext{
That even with the highest proportion of females members in the MPC (50\% since 2003) (see Farvaque et al., 2011)

Some websites, such as the Worldwide Guide to Women in Leadership, wrongly include female Central Bank chairs: Ms Ellen Johnson Sirleaf (the current president of Liberia); Violeta Asfura in Venezuela; Felisa Miceli Jsefina (former Minister of Economy and Production of Argentina, 2005-2007); Ana Dias Lourenco (former Ministry of Planning in Angola). On Guatemala, there is confusion between Ms. Lilly Zapata and Mr. Willy Zapata Waldemar Sagastume (President of the Banco Central, 1993-1997).
} 
Table 1

Central Banks with female chairs.

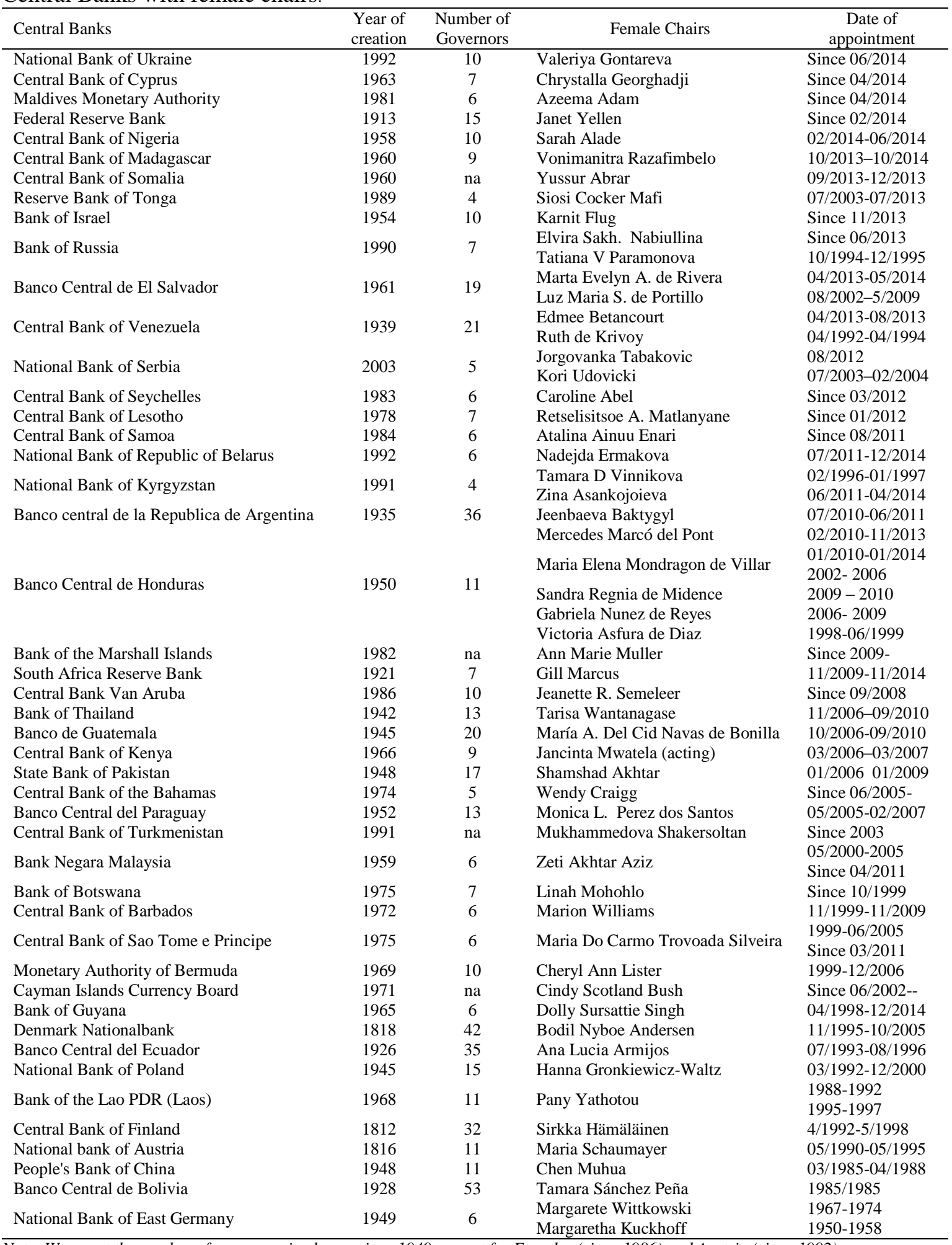

Note: We count the number of governors in charge since 1949, except for Ecuador (since 1986) and Austria (since 1992).

The majority of female Central Bank chairs were appointed in emerging countries. Among the 46 Central Banks listed, only seven (Belarus, East Germany, Russia, Serbia, Honduras, 
Kyrgyzstan) have been chaired by women more than once ${ }^{3}$ since 1949 . Similarly, those with a high turnover rate have only one nomination. Thus, the Banco Central de Bolivia has only one female (less than 2\%) among its 53 successive governors; Banco Central de la Republica de Argentina, one out of 36 (2.7\%); Banco Central del Ecuador, one out of 35, (2.8\%); Central Bank of Finland, one out of $32(3 \%)$.

Many arguments have been put forward to explain this under-representation, including: the conservative and reactionary ideology of Central Banks; the stereotypes in children's education related to customs, religion; the differentiated educational guidance received by boys and girls in terms of curriculum preparing them for the world of work; the absence, in some countries, of gender-positive policies; the way Central Bank chairs are appointed with a sort of natural bias in favor of men ${ }^{4}$.

These arguments pose the existence of circumstances that are more or less favorable to the promotion of female as Central Bank chairs. What are those circumstances? What are their characteristics? To highlight them, we will refer to the socio-economic and socio-political indicators established by the United Nations Development Program (UNDP).

\subsection{The socio-economic indicators}

They concern the Human Development Index (HDI) and the Gender Inequality Index (GII). The HDI measures the average level of human development achieved in a country in three basic dimensions: health and life expectancy, access to education and decent standards of living. Its value is between 0 and 1 . The higher the index, the higher the number of people in the country enjoying significant well-being. Depending on the HDI value, UNDP ranks 195 countries or territories in four categories: very High human development (49 countries); High human development (52 countries); Medium human development (41 countries); Low human development (42 countries). Eight countries are not classified. From the available data, table 2 shows countries with female Central Bank chairs.

By crossing data from tables 1 and 2, among the 56 female Central Bank chairs: Ten are from nine of the 49 countries classified as Very High human development; seventeen, from thirteen countries of the 52 ranked in High human development; nineteen, from fourteen countries of the 41 ranked in Medium human development; five, from five of the 42 countries classified as low human development; two, from eight unclassified countries.

\footnotetext{
Of the 56 female Central Bank chairs, 4 were named twice at different periods (Ms. María Elena Mondragón Villar in Honduras; Ms Zeti Akhtar Aziz in Malaysia; Ms Yathotou Pany in Lao PDR; Ms Maria Do Carmo Trovoada in Sao Tome principle). In total, there are thus 60 nominations.

4 See interviews of female Central Bank chairs in Central Banking Journal, Vol. XI, No. 3, Feb 16, 2001.
} 
Table 2

Indicators of Human Development 2013.

\begin{tabular}{|c|c|c|c|c|c|c|c|}
\hline & Country & $\begin{array}{l}\text { HDI } \\
\text { rank }\end{array}$ & $\begin{array}{c}\text { Human } \\
\text { Development } \\
\text { value }\end{array}$ & $\begin{array}{c}\text { Gender } \\
\text { Inequality } \\
\text { Index value }\end{array}$ & $\begin{array}{c}\text { GII } \\
\text { rank }\end{array}$ & $\begin{array}{c}\text { Share of } \\
\text { seats in } \\
\text { parliament }\end{array}$ & $\begin{array}{c}\text { Number of } \\
\text { female Central } \\
\text { Bank chairs } \\
\end{array}$ \\
\hline \multirow{9}{*}{$\begin{array}{l}\text { Very high human } \\
\text { development } \\
(\text { HDI }>0,80)\end{array}$} & United States & 5 & 0.914 & 0.262 & 47 & 18.2 & 1 \\
\hline & Germany & 6 & 0.911 & 0.046 & 3 & 32.4 & 2 \\
\hline & Denmark & 10 & 0.900 & 0.056 & 5 & 39.1 & 1 \\
\hline & Israel & 19 & 0.888 & 0.101 & 17 & 22.5 & 1 \\
\hline & Austria & 21 & 0.881 & 0.056 & 5 & 28.7 & 1 \\
\hline & Finland & 24 & 0.879 & 0.075 & 11 & 42.5 & 1 \\
\hline & Cyprus & 32 & 0.845 & 0.136 & 23 & 10.7 & 1 \\
\hline & Poland & 35 & 0.834 & 0.139 & 26 & 21.8 & 1 \\
\hline & Argentina & 49 & 0.808 & 0.381 & 74 & 37.7 & 1 \\
\hline \multirow{13}{*}{$\begin{array}{l}\text { High human } \\
\text { development } \\
(0,80>\text { HDI > } \\
0,70)\end{array}$} & Bahamas & 51 & 0.789 & 0.316 & 53 & 16.7 & 1 \\
\hline & Belarus & 53 & 0.786 & 0.152 & 28 & 29.5 & 2 \\
\hline & Russia & 57 & 0.778 & 0.314 & 52 & 12.1 & 2 \\
\hline & Barbados & 59 & 0.776 & 0.350 & 66 & 21.6 & 1 \\
\hline & Malaysia & 62 & 0.773 & 0.210 & 39 & 13.9 & 1 \\
\hline & Venezuela & 67 & 0.764 & 0.464 & 96 & 17.0 & 2 \\
\hline & Seychelles & 71 & 0.756 & na & na & 43.8 & 1 \\
\hline & Serbia & 77 & 0.745 & na & na & 33.2 & 2 \\
\hline & Ukraine & 83 & 0.734 & 0.326 & 61 & 9.4 & 1 \\
\hline & Thailand & 89 & 0.722 & 0.364 & 70 & 15.7 & 1 \\
\hline & China & 91 & 0.719 & 0.202 & 37 & 23.4 & 1 \\
\hline & Ecuador & 98 & 0.711 & 0.429 & 82 & 38.7 & 1 \\
\hline & Tonga & 100 & 0.705 & 0.458 & 90 & 3.6 & 1 \\
\hline \multirow{14}{*}{$\begin{array}{l}\text { Medium human } \\
\text { development } \\
(0,70>\text { HDI }> \\
0,55)\end{array}$} & Maldives & 103 & 0.698 & 0.283 & 49 & 6.5 & 1 \\
\hline & Turkmenistan & 103 & 0.698 & $\mathrm{Na}$ & na & 16.8 & 1 \\
\hline & Samoa & 106 & 0.694 & 0.517 & 111 & 4.1 & 1 \\
\hline & Botswana & 109 & 0.683 & 0.486 & 100 & 7.9 & 1 \\
\hline & Paraguay & 111 & 0.676 & 0.457 & 88 & 18.4 & 1 \\
\hline & Bolivia & 113 & 0.667 & 0.472 & 97 & 30.1 & 1 \\
\hline & El Salvador & 115 & 0.662 & 0.441 & 85 & 26.2 & 2 \\
\hline & South Africa & 118 & 0.658 & 0.461 & 94 & 41.1 & 1 \\
\hline & Guyana & 121 & 0.638 & 0.524 & 113 & 31.3 & 1 \\
\hline & Guatemala & 125 & 0.628 & 0.523 & 112 & 13.3 & 1 \\
\hline & Kyrgyzstan & 125 & 0.628 & 0.348 & 64 & 23.3 & 2 \\
\hline & Honduras & 129 & 0.617 & 0.482 & 99 & 19.5 & 4 \\
\hline & Lao PDR & 139 & 0.569 & 0.534 & 118 & 25.0 & 1 \\
\hline & Sao Tome \& Principe & 142 & 0.558 & na & na & 18.2 & 1 \\
\hline \multirow{5}{*}{$\begin{array}{l}\text { Low human } \\
\text { development } \\
\text { (HDI < 0,550) }\end{array}$} & Pakistan & 146 & 0.537 & 0.563 & 127 & 24,5 & 1 \\
\hline & Kenya & 147 & 0.535 & 0.548 & 122 & 19.9 & 1 \\
\hline & Nigeria & 152 & 0.504 & na & na & 6.6 & 1 \\
\hline & Madagascar & 155 & 0.498 & na & na & 15.8 & 1 \\
\hline & Lesotho & 162 & 0.486 & 0.557 & 126 & 26.8 & 1 \\
\hline \multirow{2}{*}{$\begin{array}{l}\text { Others countries } \\
\text { or territories }\end{array}$} & Marshall Islands & na & na & na & na & 3.0 & 1 \\
\hline & Somalia & na & na & na & na & 13.8 & 1 \\
\hline
\end{tabular}

Female Central Bank chairs are, hence, mostly to be found in Medium human development countries (33.9\% of the total). Then respectively in: High human development countries (30.3\%); Very high human development countries (17.8\%); Low human development countries $(8.9 \%)$. This distribution shows there is no obvious relationship between the countries' level of human development and female Central Bank chair appointments. 


\subsection{Inequality gaps between men and women}

Those are measured by the Gender Inequality Index (GII), which provides a measure of the losses in terms of human development caused by inequalities between women and men in the three dimensions of reproductive health, empowerment and the labor market. Its value varies from 0 (situation in which women have a salary equal to men) to 1 (situation in which the status of women is as bad as possible).

By crossing available data from tables 1 and 2, among the 56 female Central Bank chairs:

Five $(8.9 \%$ of the total) are from 4 countries, out of the $15(0 \leq \mathrm{GII}<0.1)$, where the treatment of women is almost identical to that of men; nine (16.0\%) from 8 countries, out of the $35(0.1 \leq \mathrm{GII}<0.3)$, where the treatment of women is similar to that of men; twenty-two (39.3\%) from 15 , of the 52 countries $(0.3 \leq \mathrm{GII}<0.5)$, where the treatment of women is quite remote from that of men; seven $(12.5 \%)$ from 7 countries, out of the $85(0.5 \leq \mathrm{GII})$, where the treatment of women is very remote from that of men.

These different distributions indicate that the socio-economic indicators of female/male inequality gaps, as measured by the Gender Inequality Index (GII), have more influence than the level of human development, measured by the Human Development Index (HDI) for the access of women to Central Bank chairmanship.

\subsection{Socio-political characteristics}

They are observed from three types of indicators: the importance of the females' political representation; the political system; the dominant religion.

The importance of the females' political representation is measured by their weight in Parliament. In the UNDP ranking, only Rwanda has a female majority in Parliament. It has not, however, appointed a female Central Bank chair. The analysis of data from tables 1 and 2 shows where women have in the Parliament:

A) Under $10 \%$ of the seats, there are seven female Central Bank chairs (12.5\% of the total) in 6 countries out of a total of 33;

B) Between $10 \%$ and $30 \%$ of the seats, there are thirty-four female Central Bank chairs $(60.7 \%$ of total) in 17 countries out of 153 ;

C) Between $30 \%$ and $50 \%$ of the seats, twelve women have succeeded to one another at the Central Bank chair $(17.8 \%)$ in 10 countries out of a total of 32.

This distribution helps establish a relationship between the relative importance of the females' political representation and their appointment as Central Bank chairs. 
As for the nature of the organization of the political system, countries can be divided into four subsets of political systems ${ }^{5}$ (western-style democracies, former popular democracies, monarchies, others):

Table 3

The political systems. Western-style democracies Former popular democracies Others Constitutional monarchies

Argentina; Austria; Bolivia; Botswana; Cyprus; Ecuador; El Salvador; Finland; Guatemala; Guyana; Honduras; Kenya; Maldives; Marshall Islands; Paraguay; Israel; Madagascar; Nigeria; Pakistan;

Belarus; China; East Germany; Lao PDR; Kyrgyzstan; Poland; Russia; Serbia; Turkmenistan; Ukraine
Bahamas; Barbados;

Bermuda; Cayman Islands; Denmark; Lesotho;

Malaysia; Samoa; Thailand;

Tonga; Van Aruba

Sao Tome e Principe; Seychelles; South Africa; United States; Venezuela

24 countries, twenty nine female

10 countries, fifteen female Central Bank chairs Central Bank chairs

11 countries, eleven female Central Bank chairs

Crossing data from tables 1 and 3 shows the earliest female Central Bank chair appointments were made in countries claiming progressive ideology, namely: East Germany (1950, 1967); China (1985); Lao PDR (1988); Poland (1992); Russia (1994, 2013); Belarus (1996, 2011); Kyrgyzstan (2010, 2011); Serbia (2003, 2012); Turkmenistan (2003); Ukraine (2014). These countries have quickly promoted the emancipation of women through the implementation of gender-friendly policies so as to ensure equality between men and women in all spheres of society: political, economic, cultural, educational and family life. For example, in China, in 1954, the constitution stipulated equality between men and women and, in 1956, a law was passed to protect the rights and interests of women (Cox-Fill, 1996).

The 56 female Central Bank chairs are divided as follows: 24 in the Western-type democratic countries; 10 in the former people's democracies; 11 in the constitutional monarchies; one in a country with another political system.

Thus, even though the former people's democracies did make the first appointments of female Central Bank chairs, their number is twice as important in countries whose organization is based on the model of Western democracy; they account for $51.7 \%$ of appointments compared to $26.7 \%$ for former people's democracies against $19.6 \%$ for constitutional monarchies. Finally, the weight of tradition and/or the characteristics of the majority religion may more or less influence the role and status of women in society. Indeed, some factors related to traditions influence economic choices and the economic development

With the exception of Denmark, Finland and the United State, all countries are in democratic transition: free elections are held periodically. But in most, there is no social compromise and not really thorough legal system. 
process (Alesina and Giuliano, 2013). By and large, these factors can be approached in reference to the geographical location of countries.

Table 4

Number of female Central Bank chairs distributed by Continent and Country.

\begin{tabular}{|c|c|c|c|}
\hline Europe & America & Africa and Indian Ocean & $\begin{array}{l}\text { Asia, Indian-subcontinent and } \\
\text { the Pacific }\end{array}$ \\
\hline $\begin{array}{l}\text { Austria (1); Belarus (2); } \\
\text { Cyprus (1); Denmark (1); } \\
\text { East Germany (2); Finland } \\
\text { (1); Poland (1); Russia (2); } \\
\text { Serbia (2); Ukraine (1) }\end{array}$ & $\begin{array}{l}\text { Argentina (1); Bahamas (1); Barbados (1); } \\
\text { Bermuda (1); Bolivia (1); Cayman Islands } \\
\text { (1); Ecuador (1); El Salvador (2); } \\
\text { Guatemala (1); Guyana (1); Honduras (4); } \\
\text { Marshall Islands (1); Paraguay (1); } \\
\text { Samoa (1); United States (1); Van Aruba } \\
\text { (1); Venezuela (2) }\end{array}$ & $\begin{array}{l}\text { Botswana (1); Kenya (1); } \\
\text { Lesotho (1); Madagascar (1); } \\
\text { Nigeria (1); Sao Tome e } \\
\text { Principe (1); Seychelles (1); } \\
\text { Somalia (1); South Africa (1) }\end{array}$ & $\begin{array}{l}\text { China (1); Israel (1); } \\
\text { Kyrgyzstan (2); Lao PDR (1); } \\
\text { Malaysia (1); Maldives (1); } \\
\text { Pakistan (1); Thailand; Tonga } \\
\text { (1); Turkmenistan (1) }\end{array}$ \\
\hline $\begin{array}{l}10 \text { countries, } 14 \text { female } \\
\text { Central Bank chairs }\end{array}$ & $\begin{array}{l}16 \text { countries, } 22 \text { female Central Bank } \\
\text { chairs }\end{array}$ & $\begin{array}{l}9 \text { countries, } 9 \text { female Central } \\
\text { Bank chairs }\end{array}$ & $\begin{array}{l}10 \text { countries, } 11 \text { female } \\
\text { Central Bank chairs }\end{array}$ \\
\hline
\end{tabular}

The 56 female Central Bank chairs are distributed in 46 countries belonging, geographically, to the mainland: America, 17 countries, including 11 in South America; Europe, 10 countries; Asian, Pacific and the Indian subcontinent, 10 countries; Africa and the Indian Ocean, 9 countries.

Thus, the American continent has the highest proportion of female Central Bank chairs (39.2\% of the total), followed by: Europe (25\%); Asia, the Indian subcontinent and the Pacific (19.6\%); Africa and the Indian Ocean (16.07\%).

The weight of religion impacts the countries' development processes (Barro and McCleary, 2003). In particular, according to the importance given to the family, the women's status in the society, it can encourage more or less the female professional careers. If we take into account religion, countries with female Central Bank chairs are distributed as follows:

Table 5

Distribution of countries by majority religion (at percentage).

\begin{tabular}{lcccc}
\hline & Christian & Jewish & Buddhist/Taoist & Others \\
\hline Argentina & $70-90$ & & \\
Austria & 90 & & \\
Bahamas & 81 & & \\
Barbados & 67 & & \\
Belarus & 55 & & \\
Bermuda & 90 & & \\
Bolivia & 76 & & \\
Botswana & 70 & & \\
China & & & \\
Cayman Islands & 81 & & \\
Cyprus & 78 & & \\
Denmark & 77,8 & & \\
Ecuador & 80 & & \\
El Salvador & 83 & & \\
Finland & 75 & & \\
East Germany & 85 & & \\
Guatemala & 87 & & \\
Guyana & 57 & & \\
Honduras & 87 & & \\
Israel & & & \\
\hline
\end{tabular}




\begin{tabular}{|c|c|c|c|c|}
\hline Kenya & 82,6 & & & \\
\hline Kyrgyzstan & & & 80 & \\
\hline Lao PDR & & 67 & & \\
\hline Lesotho & 90 & & & \\
\hline Madagascar & & & & 52 \\
\hline Malaysia & & & 62 & \\
\hline Maldives & & & 99 & \\
\hline Marshall Islands & 97 & & & \\
\hline Nigeria & 50,8 & & & \\
\hline Pakistan & & & 98 & \\
\hline Paraguay & 96 & & & \\
\hline Poland & 87,5 & & & \\
\hline Russian Federation & 41 & & & \\
\hline Samoa & 98 & & & \\
\hline Sao Tome \& Principe & 82 & & & \\
\hline Serbia & 85 & & & \\
\hline Seychelles & 90 & & & \\
\hline Somalia & & & 99,8 & \\
\hline South Africa & 80 & & & \\
\hline Thailand & & 94 & & \\
\hline Tonga & 83 & & & \\
\hline Turkmenistan & & & 89 & \\
\hline Ukraine & 72 & & & \\
\hline United States & 70 & & & \\
\hline Van Aruba & 81 & & & \\
\hline Venezuela & 92 & & & \\
\hline
\end{tabular}

When classifying religions into three subsets (Christian-Jewish, Muslim-others BuddhistTaoist), and crossing data from tables 1 and 5, it appears that 56 female Central Bank chairs are located in: 36 predominantly Christian (Catholic, Orthodox, Lutheran) and Jewish countries; 7 countries where the majority is Muslim-others; 3 countries where Buddhist-Taoist is predominant. Countries with a majority of Christian-Jewish therefore account for $80.0 \%$ of female Central Bank chairs against $14.3 \%$ in the countries where Muslim-others is predominant, and $5.35 \%$ with a majority of Buddhist/Taoist.

Thus, the observation of countries with female Central Bank chairs, according to socioeconomic criteria (level of human development (HDI), gap of inequality of treatment between men and women (GII)), socio-political criteria (nature of the political organization, weight of cultural traditions, majority religion) shows that:

A) Female Central Bank chair nominations seem correlated to the relative weight of tradition, the majority religion and the gap in treatment between men and women;

B) There is no obvious relationship between the countries' level of human development and the female Central Bank chairs named.

As shown by table 1 , there is a small minority of women in the closed world of Central Banks. This situation is partly due to the fact that appointing Central Bank chairs is strictly the government or parliament prerogative. Hence, it would appear important to focus on the profile of appointed female Central Bank chairs. 


\subsection{Female Central Bank chairs: academic and career backgrounds}

To analyze the profile of female Central Bank chairs, we collected biographical data available from the websites of national Central Banks and supplemented them with those available from other websites. Data are summarized in table 6.

Central Bank chair preferences, on monetary policy goals, are influenced by their career background. That is the case when he is encouraged to express his loyalty to some lobbies, an industry, a political party or a bureaucracy. In particular, a past career as Central Bank staff may encourage executives to identify their own interests with the Central Bank's goals. Indeed, as an institution, the Central Bank seeks to build up a reputation and maintain credibility. Those reputation and credibility are based on its ability to fulfill its mission, mainly summarized by maintaining price stability. Compared to a previous career as a politician or official (including international civil servants), the Central Bank chair is prompted to a stronger preference for price stability ${ }^{6}$. Those differences stem from motivations that are linked with redistribution policies, real state debt reduction, stimulus policy. A past career in the private sector (in companies, financial and banking sectors) will influence the Central Bank chair's preferences in the direction of business satisfaction. All in all, officers with a background as Central Bank staff members, as business executives (insurance companies, commercial banks, managerial sector) or as public servant have, on average, a stronger preference for price stability than those with a background as politicians or trade-unionists.

A scrutiny of female Central Bank chairs career background data reveals that: $71.4 \%$ have held various responsibilities within the Central Bank as vice-chair, board member, economist or department manager; $40.8 \%$ have had experience in banking and/or finance and insurance; $26.5 \%$ have taught as university professors or assistants; $51.0 \%$ have worked in the public sector; against $39.6 \%$ for the private sector; $39.6 \%$ have been very active in politics as members of parliament, ministers, prime ministers; $33.3 \%$ have worked for international institutions such as IMF, World Bank, UNPD.

From the Public Choice perspective, Central Bank chairs' preferences have influence on the monetary policy goals. Hence, it is in the service of their own interests or special interest groups. For example, a past of commercial banker will lead to the capture of the Central Bank to the banking sector. 
Table 6

Data on the academic and career backgrounds.

\begin{tabular}{|c|c|c|c|c|c|c|c|c|c|c|c|c|c|c|}
\hline \multirow[b]{2}{*}{ Central Banks } & \multirow[b]{2}{*}{ Governors } & \multicolumn{7}{|c|}{ Career background } & \multicolumn{6}{|c|}{ Academic background } \\
\hline & & 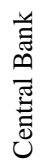 & 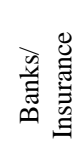 & 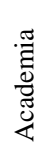 & 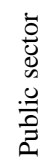 & 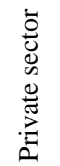 & $: \stackrel{0}{0}$ & 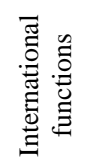 & 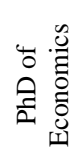 & 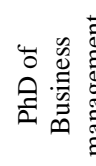 & 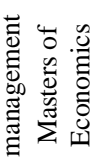 & 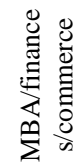 & $\begin{array}{l}\frac{\overrightarrow{0}}{0} \\
\overline{\tilde{g}} \\
\emptyset\end{array}$ & $\frac{\tilde{\omega}}{\stackrel{\Xi}{0}}$ \\
\hline Ukraine & Valeriya Gontareva & & $\mathrm{X}$ & & $\mathrm{X}$ & $\mathrm{X}$ & & & & & $\mathrm{X}$ & & & \\
\hline Cyprus & Chrystalla Georghadji & & $\mathrm{X}$ & & $\mathrm{X}$ & & & & & & & & & \\
\hline Maldives & Azeema Adam & $\mathrm{X}$ & & & $\mathrm{X}$ & & & & $\mathrm{X}$ & & & & & \\
\hline US & Janet Yellen & $\mathrm{X}$ & & $\mathrm{X}$ & $\mathrm{X}$ & & & $\mathrm{X}$ & $\mathrm{X}$ & & & & & \\
\hline Nigeria & Sarah Alade & $\mathrm{X}$ & & $\mathrm{X}$ & $\mathrm{X}$ & & & & & $\mathrm{X}$ & & & & \\
\hline Madagascar & Vonimanitra Razafimbelo & $\mathrm{X}$ & & & $\mathrm{X}$ & & & & & & & & & \\
\hline Somalia & Yussur Abrar & & $\mathrm{X}$ & & & $\mathrm{X}$ & & & & & & $\mathrm{X}$ & & \\
\hline Tonga & Siosi Cocker Mafi & $\mathrm{X}$ & & & $\mathrm{X}$ & & & & & & $\mathrm{X}$ & & & \\
\hline Israel & Karnit Flug & $\mathrm{X}$ & & & $\mathrm{X}$ & & & $\mathrm{X}$ & $\mathrm{X}$ & & & & & \\
\hline \multirow{2}{*}{ Russia } & Elvira Sakhipzadovna Nabiullina & & $\mathrm{X}$ & & $\mathrm{X}$ & $\mathrm{X}$ & $\mathrm{X}$ & & $\mathrm{X}$ & & & & & \\
\hline & Tatiana V Paramonova & $\mathrm{X}$ & $\mathrm{X}$ & & & $\mathrm{X}$ & & & $\mathrm{X}$ & & & & & \\
\hline \multirow{2}{*}{ El Salvador } & Marta Evelyn Arévalo de Rivera & $\mathrm{X}$ & $\mathrm{X}$ & $\mathrm{X}$ & & & & & & & $\mathrm{X}$ & & & \\
\hline & Luz Maria Serpas de Portillo & $\mathrm{X}$ & $\mathrm{X}$ & & & & & & & & $\mathrm{X}$ & & & \\
\hline \multirow{2}{*}{ Venezuela } & Edmee Betancourt & & $\mathrm{X}$ & $\mathrm{X}$ & $\mathrm{X}$ & & $\mathrm{X}$ & & & & & & & $\mathrm{X}$ \\
\hline & Ruth de Krivoy & $\mathrm{X}$ & $\mathrm{X}$ & $\mathrm{X}$ & $\mathrm{X}$ & $\mathrm{X}$ & $\mathrm{X}$ & $\mathrm{X}$ & $\mathrm{X}$ & & & & & \\
\hline \multirow{2}{*}{ Serbia } & Jorgovanka Tabakovic & & & & & & $\mathrm{X}$ & & $\mathrm{X}$ & & & & & \\
\hline & Kori Udovicki & & & $\mathrm{X}$ & $\mathrm{X}$ & & $\mathrm{X}$ & $\mathrm{X}$ & $\mathrm{X}$ & & & & & \\
\hline Seychelles & Caroline Abel & $\mathrm{X}$ & & & & & & & & & $\mathrm{X}$ & & & \\
\hline Lesotho & Rets'elisitsoe Adelaide Matlanyane & $\mathrm{X}$ & & $\mathrm{X}$ & & & & & $\mathrm{X}$ & & & & & \\
\hline Samoa & Atalina Ainuu Enari & $\mathrm{X}$ & & & & & & & & & $\mathrm{X}$ & & & \\
\hline \multirow{2}{*}{ Belarus } & Nadejda Ermakova & $\mathrm{X}$ & $\mathrm{X}$ & & $\mathrm{X}$ & & & & & & & $\mathrm{X}$ & & \\
\hline & Tamara D Vinnikova & & $\mathrm{X}$ & & & & & & & & & & & \\
\hline \multirow{2}{*}{ Kyrgyzstan } & Zina Asankojoieva & $\mathrm{X}$ & & & $\mathrm{X}$ & & & & & & & $\mathrm{X}$ & & \\
\hline & Jeenbaeva Baktygyl & $\mathrm{X}$ & $\mathrm{X}$ & & $\mathrm{X}$ & $\mathrm{X}$ & & $\mathrm{X}$ & & & $\mathrm{X}$ & & & \\
\hline \multirow[t]{2}{*}{ Argentina } & Mercedes Marcó del Pont & & $\mathrm{X}$ & $\mathrm{X}$ & $\mathrm{X}$ & $\mathrm{X}$ & $\mathrm{X}$ & $X$ & $\mathrm{X}$ & & & & & \\
\hline & $\begin{array}{l}\text { María Elena Mondragón de Villar } \\
\text { Sandra Regnia de Midence }\end{array}$ & $X$ & & & $\mathrm{X}$ & $\mathrm{X}$ & & & & & $\mathrm{X}$ & & & \\
\hline \multirow[t]{2}{*}{ Honduras } & Gabriela Nunez de Reyes & $\mathrm{X}$ & $\mathrm{X}$ & $\mathrm{X}$ & $\mathrm{X}$ & $\mathrm{X}$ & $\mathrm{X}$ & $\mathrm{X}$ & & & $\mathrm{X}$ & & & \\
\hline & Victoria Asfura de Diaz & $\mathrm{X}$ & & & & & & & & & & $\mathrm{X}$ & & \\
\hline Marshall Islands & Ann Marie Muller & & & & & & & & & & & & & \\
\hline Van Aruba & Jeanette R. Semeleer & $\mathrm{X}$ & & & $\mathrm{X}$ & & & & & & $\mathrm{X}$ & & & \\
\hline South Africa & Gill Marcus & $\mathrm{X}$ & $\mathrm{X}$ & $\mathrm{X}$ & & $\mathrm{X}$ & $\mathrm{X}$ & & & & & & $\mathrm{X}$ & \\
\hline Thailand & Tarisa Wantanagase & $\mathrm{X}$ & & & & & & $\mathrm{X}$ & $\mathrm{X}$ & & & & & \\
\hline Guatemala & María A. Del Cid Navas de Bonilla & $\mathrm{X}$ & & & $\mathrm{X}$ & $\mathrm{X}$ & $\mathrm{X}$ & $\mathrm{X}$ & & & $\mathrm{X}$ & & & \\
\hline Kenya & Jancinta Mwatela & $\mathrm{X}$ & & & & & $\mathrm{X}$ & & & & & $\mathrm{X}$ & & \\
\hline Pakistan & Shamshad Akhtar & $\mathrm{X}$ & $\mathrm{X}$ & & $\mathrm{X}$ & & & $\mathrm{X}$ & $\mathrm{X}$ & & & & & \\
\hline Bahamas & Wendy Craigg & $\mathrm{X}$ & $\mathrm{X}$ & & & & & & & & $\mathrm{X}$ & & & \\
\hline Paraguay & Monica Lujan Perez dos Santos & $\mathrm{X}$ & & & & & & $\mathrm{X}$ & $\mathrm{X}$ & & & & & \\
\hline Turkmenistan & Mukhammedova, Shakersoltan & & & & & & & & $\mathrm{Na}$ & na & na & na & na & na \\
\hline Malaysia & Zeti Akhtar Aziz & $\mathrm{X}$ & & & & & & $\mathrm{X}$ & $\mathrm{X}$ & & & & & \\
\hline Botswana & Linah Mohohlo & $\mathrm{X}$ & & & & $\mathrm{X}$ & & $\mathrm{X}$ & & & & $\mathrm{X}$ & & \\
\hline Barbados & Marion Williams & $\mathrm{X}$ & & & & & & $\mathrm{X}$ & $\mathrm{X}$ & & & & & \\
\hline Sao Tome Principe & Maria Do Carmo Trovoada Silveira & & & & & & $\mathrm{X}$ & & & & & $\mathrm{X}$ & & \\
\hline Bermuda & Cheryl Ann Lister & & $\mathrm{X}$ & & & & & & & & & $\mathrm{X}$ & & \\
\hline Cayman Islands & Cindy Scotland Bush & $\mathrm{X}$ & & & $\mathrm{X}$ & & & & & & & & $\mathrm{X}$ & \\
\hline Guyana & Dolly Sursattie Singh & & & & & & & & & & & & & \\
\hline Denmark & Bodil Nyboe Andersen & $\mathrm{X}$ & $\mathrm{X}$ & $\mathrm{X}$ & & $\mathrm{X}$ & $\mathrm{X}$ & & & & & $\mathrm{X}$ & & \\
\hline Ecuador & Ana Lucia Armijos & $\mathrm{X}$ & & & & & $\mathrm{X}$ & $\mathrm{X}$ & & & $\mathrm{X}$ & & & \\
\hline Poland & Hanna Gronkiewicz-Waltz & & & $\mathrm{X}$ & & $\mathrm{X}$ & $\mathrm{X}$ & & $\mathrm{X}$ & $\mathrm{X}$ & & & & \\
\hline Laos & Pany Yathotou & $\mathrm{X}$ & & & & & $\mathrm{X}$ & & & & & & $\mathrm{X}$ & \\
\hline Finland & Sirkka Hämäläinen & $\mathrm{X}$ & & $\mathrm{X}$ & & $\mathrm{X}$ & & & & $\mathrm{X}$ & & & & \\
\hline Austria & Maria Schaumayer & & $\mathrm{X}$ & & $\mathrm{X}$ & $\mathrm{X}$ & $\mathrm{X}$ & & & $\mathrm{X}$ & & & & \\
\hline China & Chen Muhua & & & & & $\mathrm{X}$ & $\mathrm{X}$ & & & & & & & $\mathrm{X}$ \\
\hline Bolivia & Tamara Sánchez Peña & na & & & & & & & & & & & & \\
\hline Fast Germany & Margarete Kuckhoff & & & & $\mathrm{X}$ & $\mathrm{X}$ & $\mathrm{X}$ & & & & & $\mathrm{X}$ & & \\
\hline East Germany & Margaretha Wittkowski & & & & $\mathrm{X}$ & $\mathrm{X}$ & $\mathrm{X}$ & & & $\mathrm{X}$ & & & & \\
\hline
\end{tabular}

Sources: websites: Bank for International Settlements; The Group of Thirty; Women in Sovereign Entities; periodic reviews: World Who's who - Marquis Who's who; The Banker; Europa Year Book. 
Thus, a vast majority of female Central Bank chairs held various positions in the Central Bank before being appointed. Many worked in the public and private sectors and they had experience in the banking and financial sectors. A significant proportion was very active in politics. It would thus seem that the profiles of these female Central Bank chairs seem to tilt the preferences in favor of price stability.

The ability to understand economic and inflation mechanisms depends on their academic background. From a Public Choice perspective, the Central Bank chairs are driven by their own narrow professional perspectives and ambitions. With an economist's profile will normally have an advantage enabling him to influence policy decisions in favor of his own preferences or specific targets (Acheson and Chant, 1973). A more business-oriented training (managers, engineers) will predispose the Central Bank chair to greater aversion to inflation. Indeed, price stability is a major asset for the economy and business development (Mishkin, 2007).

The academic background data for female Central Bank chairs reveal (see table 6) that $40.8 \%$ of them hold a $\mathrm{PhD}$ or equivalent (in economics for $31.2 \%$ for them against $10.4 \%$ in business and management); $48.98 \%$ hold a Master's degree or equivalent (including $31.25 \%$ specialized in economics and $18.7 \%$ in finance or business administration or commerce); $6.12 \%$ a specialized Bachelor or equivalent in economics, finance, commerce or accounting techniques; $4.08 \%$ another diploma or certificate (accounting, engineering).

Thus, female Central Bank chairs mostly possess technical skills to influence monetary policy decisions in the direction of their preferences. Even if a significant proportion holds a business-related diploma, it would be premature to infer their preferences between various potential monetary policy goals. Overall, the analysis of data related to the female Central Bank chairs career background leads us to the conclusion that, concerning the monetary policy goals, their preferences mostly go towards price stability. The examination of their academic training shows that they have the ability to assert their preferences. However, only the results of the empirical analysis can robustly establish the exact nature of their preferences with respect to price stability, in comparison with male Central Bank chairs. To this aim, the model we are presenting hereafter has been designed to estimate the policy parameter of female Central Bank chairs compared to their male counterparts. 


\section{Gender and the inflation/output trade-off}

In the literature about the optimal monetary policy, it is standard to assume that monetary authorities operate by following a targeting rule, as defined by Svensson (1999). The Central Bank chair is supposed to minimize a quadratic loss function $\mathrm{L}_{t}$, which penalizes deviations of the objective variables from their target. Let us assume that these objective variables are the output gap $\mathrm{x}_{\mathrm{t}}$ (the deviation of the actual GDP from its potential value) and the inflation rate $\pi_{t}$, which the Central Bank chair wants as close as possible to zero and the inflation target $\bar{\pi}$. The quadratic loss function is specified as

$$
\mathrm{L}_{\mathrm{t}}=\alpha \mathrm{x}_{\mathrm{t}}^{2}+\mathrm{E}_{\mathrm{t}}\left[\left(\pi_{\mathrm{t}+1}-\bar{\pi}\right)^{2}\right]+\sum_{\mathrm{i}=1}^{\infty} \beta^{\mathrm{i}} \mathrm{E}_{\mathrm{t}}\left(\alpha \mathrm{x}_{\mathrm{t}+\mathrm{i}}^{2}+\left(\pi_{\mathrm{t}+1+\mathrm{i}}-\bar{\pi}\right)^{2}\right), \quad 0<\beta<1, \alpha \geq 0
$$

where $\beta$ is an intertemporal discount factor and $\alpha$ represents preferences of the Central Bank chair regarding the stabilization of the output, relatively to the stabilization of the inflation rate around its target $\bar{\pi}$. This quadratic loss function is a slightly modified version of the loss function frequently used in the literature, with the present quadratic inflation deviation $\left(\pi_{t}-\pi\right)^{2}$ replaced with the expected value $E_{t}\left[\left(\pi_{t+1}-\bar{\pi}\right)^{2}\right]$. This is because we suppose that $\pi_{t}$ does not depend on the current monetary policy. Due to delay of the monetary transmission mechanism, the monetary policy cannot influence the contemporaneous value of the inflation rate, ant it operates only on one-year forward inflation rate anticipation. Apart from that, Eq. (1) is conventionally interpreted; the higher $\alpha$, the less conservative the Central Bank chair is in the sense of Rogoff (1985). Our aim is to estimate the value of $\alpha$ for female Central Bank chairs comparatively to their male counterparts. Are female Central Bank chairs more, less or as conservative as men?

The Central Bank chair is supposed to control the output gap $x_{t}$. At first sight it may seem too strong a hypothesis, but it is in fact a common tacit assumption in monetary models, the policy-maker setting the interest rate to control the output gap (see for example Clarida, Galí and Gertler, 1999). With this assumption, we will not need to specify a demand or 'IS' curve. This is clearly an advantage as our results are independent of the demand equation specification. The only structural equation we need to specify is a New-Keynesian Phillips equation, which is supposed to be of the form

$$
\pi_{\mathrm{t}+1}-\bar{\pi}=\lambda \mathrm{x}_{\mathrm{t}}+\beta\left(\mathrm{E}_{\mathrm{t}} \pi_{\mathrm{t}+2}-\bar{\pi}\right)+\mathrm{u}_{\mathrm{t}+1}, \quad \lambda>0,
$$


where $E_{t}$ is the expectation operator, conditional on information available at date $t$, and $u_{t+1}$ is a supply shock, eventually autocorrelated. In this forward-looking formulation of the Phillips equation, output gap affects the inflation rate with one-year lag, which is consistent with annual data according to Svensson (1997). Eq. (2) is grounded on dynamic general equilibrium theory, which keeps the Lucas critic away, and apart from the fact we suppose that there is a control lag of one year, it is of the same form as the Phillips curve considered in Clarida, Galí and Gertler (1999).

The policy problem is to choose a time path for $x_{t}$ which minimizes the loss function (1), subject to the constraint (2). This problem reduces to minimizing $\alpha x_{t}^{2}+E_{t}\left[\left(\pi_{t+1}-\bar{\pi}\right)^{2}\right]$, the controllable part of (1), subject to (2). The first order condition of this problem is $2 \alpha x_{t}+2 \lambda E_{t}\left(\pi_{t+1}-\bar{\pi}\right)=0$, which can be written

$$
-\frac{\lambda}{\alpha}\left[\mathrm{E}_{\mathrm{t}}\left(\pi_{\mathrm{t}+1}\right)-\bar{\pi}\right]=\mathrm{x}_{\mathrm{t}} \text {. }
$$

When the expected inflation rate is above (below) target, the Central Bank reduces (raises) the output gap. The aggressiveness of this response depends on parameters $\lambda$ and $\alpha$. The response is more aggressive if the influence of output gap on inflation is high ( $\lambda$ is high), and if the conservatism of the Central Bank chair is more pronounced ( $\alpha^{-1}$ is high). This last parameter is likely to depend on the personality of the policy maker. It may also depend on the economic, political context in which the Central Bank chair is doing his or her job.

Let $\varepsilon_{\mathrm{t}+1}=\pi_{\mathrm{t}+1}-\mathrm{E}_{\mathrm{t}}\left(\pi_{\mathrm{t}+1}\right)$ denote the inflation forecast error. Eq. (3) can be rearranged

$$
\pi_{\mathrm{t}+1}=\bar{\pi}-\gamma \mathrm{x}_{\mathrm{t}}+\varepsilon_{\mathrm{t}+1} \quad \gamma=\frac{\alpha}{\lambda}>0, \mathrm{E}_{\mathrm{t}}\left(\varepsilon_{\mathrm{t}+1}\right)=0 .
$$

Eq. (4) can be estimated by OLS. According to condition $\mathrm{E}_{\mathrm{t}}\left(\varepsilon_{\mathrm{t}+1}\right)=0$, errors of this model cannot be serially correlated. Eq. (4) shows that for a country whose monetary policy is consistent with the model defined by (1) and (2), the regression of $\pi_{t+1}$ on $x_{t}$ must produce a negative slope $-\gamma$ and must be characterized by a serially uncorrelated error term. But not every country's monetary policy is consistent with this model. Countries which are not consistent with it, particularly those which are not following a targeting rule described by the loss function (1), should not be included in our empirical analysis. Eq. (4) suggests that the way to select those which are consistent with the model is to look at the estimated slope and at the residuals of the regression equation (4). 
In case the Central Bank policy is not constant, depending on the current Central Bank chair, we have to make allowance for its variability. In particular, if female Central Bank chairs operate differently from their male counterparts, it should be the case that $\alpha$, and thus $\gamma$, differ depending on the gender of the policymaker. The loss function (1) would be different for men and women, in that the constant parameter $\alpha$ would be replaced with a variable parameter $\alpha^{\mathrm{t}}$. In order to generalize the model in this way, let us consider the exogenous gender indicator $d_{t}$ which can either be $d_{t}=0$ (the Central Bank chair of period $t$ is a male) or $d_{t}=1$ (the Central Bank chair of period $t$ is a female). According to the gender of the Central Bank chair, the relative weight for stabilization of the output gap in the loss function can be either $\alpha^{t}=\alpha^{M}\left(\right.$ for $\left.d_{t}=0\right)$ or $\alpha^{t}=\alpha^{F}\left(\right.$ for $\left.d_{t}=1\right)$.

So the slope of the regression of $\pi_{t+1}$ on $x_{t}$ can vary with the value of the gender indicator; it can be either $\gamma^{\mathrm{t}}=\gamma^{\mathrm{M}}=\frac{\alpha^{\mathrm{M}}}{\lambda}$ for $\left(\mathrm{d}_{\mathrm{t}}=0\right)$ or $\gamma^{\mathrm{t}}=\gamma^{\mathrm{F}}=\frac{\alpha^{\mathrm{F}}}{\lambda} \quad\left(\right.$ for $\left.\mathrm{d}_{\mathrm{t}}=1\right)$. The generalized model of the inflation/output trade-off is then

$$
\pi_{\mathrm{t}+1}=\bar{\pi}-\gamma \mathrm{x}_{\mathrm{t}}-\phi \mathrm{d}_{\mathrm{t}} \mathrm{x}_{\mathrm{t}}+\varepsilon_{\mathrm{t}+1}, \mathrm{E}_{\mathrm{t}}\left(\varepsilon_{\mathrm{t}+1}\right)=0
$$

For $\mathrm{d}_{\mathrm{t}}=0, \partial \mathrm{E}_{\mathrm{t}}\left(\pi_{\mathrm{t}+1}\right) / \partial \mathrm{x}_{\mathrm{t}}=-\gamma$ so $\gamma^{\mathrm{M}}=\gamma$, whereas for $\mathrm{d}_{\mathrm{t}}=1, \partial \mathrm{E}_{\mathrm{t}}\left(\pi_{\mathrm{t}+1}\right) / \partial \mathrm{x}_{\mathrm{t}}=-\gamma-\phi$ so $\gamma^{\mathrm{F}}=\gamma+\phi$. A positive (negative) value for $\phi$ indicates that the female Central Bank chairs are less (more) conservative than their male counterparts. More precisely, as $\frac{\gamma^{\mathrm{F}}}{\gamma^{\mathrm{M}}}=\frac{\alpha^{\mathrm{F}}}{\alpha^{\mathrm{M}}}$, we get that $\frac{\phi}{\gamma}=\frac{\alpha^{\mathrm{F}}-\alpha^{\mathrm{M}}}{\alpha^{\mathrm{M}}}$. The ratio $\phi / \gamma$ measures in percentage how much female Central Bank chairs are more cautious about output stabilization than men.

Estimating the policy preferences by the way of running the regression equation (5) is a much more simple methodology than those used in the literature (see Cecchetti and Ehrmann, 2002, Favero and Rovelli, 2003, Ozlale 2003, Castelnuovo and Surico, 2003, Tachibana 2004, Krause and Méndez, 2005, Dennis, 2006). In these aforementioned studies about the estimation of Central Banks' preferences, an identification problem arises, due to the nature of the objective. In effect, the common objective to all these studies is to get an estimate of the preference parameters. It requires estimating all the structural and preference parameters in order to recover the preference parameters from the reduced form of the model. On the contrary, our methodology is simpler (and presumable more robust to error specification) because we do not try to estimate the preference coefficients $\alpha^{\mathrm{F}}$ and $\alpha^{\mathrm{M}}$ but only to estimate 
how they differ. To do so, we don't need to estimate the structural parameter $\lambda$; it is not even necessary to estimate an aggregate demand curve. The basic principle of this methodology is borrowed from Diouf and Pépin (2010).

Estimation of policy preferences are usually based on estimation of all policy and structural parameters. These traditional estimation procedures require an estimation of the structural macroeconomic model and an interest rate rule, in order to recover all the parameters (Favero and Rovelli, 2003, Ozlale, 2003, Castelnuovo and Surico, 2003, Dennis, 2006), or of the structural macroeconomic model and the first-order equation of the loss function's minimization (Favero and Rovelli, 2003, Tachibana, 2004), using an approach close to ours. Another approach is to estimate the structural macroeconomic model and to use an estimation of the variances of inflation and output gap to recover the preference parameters (Cecchetti and Ehrmann, 2002, Krause and Méndez, 2005). More simply, we focus on the first-order condition, which solves the optimization problem faced by the Central Bank chair. Our methodology is also distinctive in preferring a forward-looking model to a backward-looking one, and using annual data (instead of quarterly data).

Estimating Eq. (4) and testing the significance of $\hat{\phi}$ (the OLS estimator of $\phi$ ) is then sufficient to find out if female and male Central Bank chairs behave similarly way or not, and in case they don't, to infer about their differences. Theoretically, we can run such a regression for every country to assess the differences between women and men. For every country, we can estimate the country parameters $\gamma$ and $\phi$. The drawback of running individual (country) regressions is that the individual estimators $\hat{\phi}$ will be imprecisely estimated if the number of observations characterized by $d_{t}=1$ is low. And it is in fact the case for almost every country that this number is very low, because of the overrepresentation of men in the Central Banks' management. If we estimate $\phi$ country by country, the variance of $\hat{\phi}$ would be high, and the estimated parameter would not be statistically significant, even if the true parameter is non zero. Thus we prefer to adopt an alternative estimation and test methodology, based on a panel data analysis. On the one hand, the drawback of such a methodology is to impose a restriction on country regressions that implies the existence of a common parameter; but on the other hand, using the panel sample produces a better estimate of this common parameter.

The panel model can be written

$$
\pi_{\mathrm{j}, \mathrm{t}+1}=\bar{\pi}_{\mathrm{j}}-\gamma_{\mathrm{j}} \mathrm{x}_{\mathrm{j}, \mathrm{t}}-\rho \gamma_{\mathrm{j}} \mathrm{d}_{\mathrm{j}, \mathrm{x}} \mathrm{x}_{\mathrm{j}, \mathrm{t}}+\varepsilon_{\mathrm{j}, \mathrm{t}+1}, \mathrm{E}_{\mathrm{t}}\left(\varepsilon_{\mathrm{j}, \mathrm{t}+1}\right)=0
$$


where $\mathrm{j}$ is introduced to identify the country $\mathrm{j}(\mathrm{j}=1 \ldots \mathrm{N})$. All the variables $\pi_{\mathrm{j}, \mathrm{t}+\mathrm{l}}, \mathrm{x}_{\mathrm{j}, \mathrm{t}}, \mathrm{d}_{\mathrm{j}, \mathrm{t}}$ and $\varepsilon_{\mathrm{j}, \mathrm{t}+1}$ are country-specific, just like the parameters $\bar{\pi}_{\mathrm{j}}$ and $\gamma_{\mathrm{j}}$. The parameter $\rho$ is common to all countries included in the panel.

By generalizing our previous notations, we can write $\gamma_{j}^{M}=\gamma_{j}=\frac{\alpha_{j}^{M}}{\lambda_{j}}$ and $\gamma_{j}^{F}=(1+\rho) \gamma_{j}=\frac{\alpha_{j}^{F}}{\lambda_{j}}$. So $\gamma_{j}^{\mathrm{F}}=(1+\rho) \gamma_{\mathrm{j}}^{\mathrm{M}}$ or in an equivalent manner $\alpha_{\mathrm{j}}^{\mathrm{F}}=(1+\rho) \alpha_{\mathrm{j}}^{\mathrm{M}}$. The common parameter $\rho$ represents the deviation of the weights given to stabilization of output by women, against the weights given by men, in percentage of the weights given by men. For example, if $\rho=0.10$, then female Central Bank chairs are 10\% more inclined to stabilize output gap than men. The panel model restricts this difference between female and male Central Bank chairs to be the same, regardless of the country considered.

Eq. (6) is a non-linear panel model, which has to be estimated by numeric methods (like Gauss-Newton). The system of $\mathrm{N}$ equations (6) can be estimated by non-linear Least Squares. But as the errors $\varepsilon_{\mathrm{j}, t+1}$ are contemporaneously correlated between countries, we implement a non-linear Seemingly Unrelated Regression (SUR) method to estimate this system, exploiting this additional information.

\section{A panel data analysis}

The macroeconomic data used is from the FMI web site. At the time we picked up the data the last update was 03/2015. We use annual GDP data (valued at constant prices in national currency) and annual end of period consumer prices index ${ }^{7}$ relative to thirty-three countries (Argentina, Austria, Bahamas, Barbados, Belarus, Bolivia, Botswana, China, Denmark, Ecuator, Salvador, Finland, Guatemala, Guyana, Honduras, Kenya, Kyrgyzstan, Lao, Lesotho, Malaysia, Marshall Islands, Pakistan, Paraguay, Poland, Russia, Samoa, Sao Tome, Serbia, Seychelles, South Africa, Tonga, Turkmenistan and Venezuela). Data are collected on the period 1980-2014 or on a shorter period for some countries ${ }^{8}$. We calculate the inflation rate for every country by applying the formula $\pi_{t}=100 \times \ln \left(\mathrm{P}_{t} / \mathrm{P}_{\mathrm{t}-1}\right)$, with $\mathrm{P}_{\mathrm{t}}$ designating the price

For Argentina and China, we use annual average consumer prices index.

For Belarus, Russia and Turkmenistan, the GDP date are available from 1992 and the inflation data from 1993; for China, the inflation data are available from 1987; for Kyrgyzstan, the GDP and inflation data are available from 1993; for Marshall Islands, the GDP data are available from 1997 and the inflation date from 2004; and for Serbia, the GDP and inflation data are available from 1998. 
index. The potential GDP is estimated by regressing the actual GDP on a quadratic trend, and the output gap is then defined by $x_{t}=100 \times \ln \left(Y_{t} / Y_{t}^{*}\right)$, with $Y_{t}$ and $Y_{t}^{*}$ for respectively the actual and potential GDP.

For every country $j$ and every year $t$ we set the dummy variable $d_{j t}$ to 1 if a female was the Central Bank chairman for at least six months. Otherwise the dummy is set to 0 . In the initial data set, seven countries have a unique $d_{t}=1$ in 2014 (Cyprus, Israel, Madagascar, Maldives, Nigeria, Ukraine and the US). As inflation depends on monetary policy with a delay of one year, and because we have not the 2015 data yet, these countries don't bring any information about the parameter of interest in this study $(\rho)$. This is why they are not included in the previous list of thirty-three countries.

\subsection{Individual regressions}

In order to select countries to be included in the panel analysis, individual regressions were run. For every country, Eq. (5) is estimated by OLS.

Some adjustments have been made for some countries, about the intercept $\bar{\pi}$ of the regression and about the sample period. These adjustments were necessary because the countries examined in the study are not similar, particularly concerning inflation rates. Firstly, some countries have experienced disinflationist processes. So the implicit inflation target $\bar{\pi}$, which equals the long term inflation rate if the Central Bank hits the target in the long run, cannot be supposed constant. So the constant intercept $\bar{\pi}$ was replaced with a quadratic trend $\mathrm{a}_{\pi}+\mathrm{b}_{\pi} \mathrm{t}+\mathrm{c}_{\pi} \mathrm{t}^{2}$. This adjustment concerns Bahamas, Botswana, Denmark, Finland, Guyana, Honduras, Lesotho, Paraguay, Poland, Russia, Sao Tome, Salvador and Serbia. To decide whether to include the quadratic term or not, we looked at the serial correlation of the residual term, by means of the Breusch-Godfrey Serial Correlation LM Test. A significant autocorrelation of residuals detected in the model without quadratic trend may indicate the existence of a trend in the inflation process. So, if we detected a significant autocorrelation of residuals, and if the inclusion of quadratic trend makes this autocorrelation disappear, we include the trend in the regression. It is worth to note that the inclusion of the quadratic trend has little impact on the estimated parameters $\hat{\gamma}$ and $\hat{\phi}$, because the output gap is a de-trended series by construction. So the inclusion of quadratic trends has no consequences on the results; it only makes the residuals' autocorrelation disappear. Secondly, adjustments have also been made on the sample period. The theoretical model described by equations (1) and 
(2) may be a good description of the monetary policy for some countries on a more recent period, but not since the early 1980s. The concept of a targeting rule is relatively recent, and few Central Banks in the world have followed such a rule since the early 1980s. For some countries included in the sample, it is obvious that the apparent inflation instability is not compatible with the inflation/output trade-off. In these countries, monetary policy was not intended to control inflation, even partially, but to fund public spending, this policy creating hyperinflation. Some of these countries have more recently regained control of inflation, and we do take these periods of stability into account when running the regressions. Argentina experienced instability of inflation process up to 1992. Before 1992, inflation measured with the logarithmic formulae, which underestimate inflation for high rates relatively to the index price growth rate, was over $60 \%$ (on the period 1980-1991). The inflation index fell from 1992 and was fairly stable since then. In Belarus, inflation has stabilized since 1996. Between 1993 and 1995, inflation was over 200\% before dropping. In Kyrgyzstan inflation rate was over 200\% in 1993 and 100\% in 1994, before dropping in 1995. In Turkmenistan, inflation stabilized below 25\% from 1998 onwards. The Polish inflation rate was unstable up to 1991. In addition, in China and in Ecuador inflation stabilized respectively from 1995 and 2002 onwards, but as there was no more female Central Bank chair from these years, we didn't shorten the sample period. Moreover, there is a lack of reliability with Paraguay's inflation data before 1990. The reported inflation rate was exactly the same (23.58702) every year from 1980 to 1989; so we excluded this period of the sample. And finally, inflation was analyzed in Austria up to 1998, as the country entered the Euro zone in 1999.

Table 7 presents the results of the individual estimations of Eq. (5). We test the hypothesis of nullity of parameters $\hat{\bar{\pi}}, \hat{a}_{\pi}, \hat{\mathrm{b}}_{\pi}, \hat{\mathrm{c}}_{\pi}$ and $\hat{\phi}$, and we test the hypothesis of negativity of $\hat{\gamma}$ (in others words we look if $\hat{\gamma}$ is significantly positive). The results show that few countries have adopted a monetary policy compatible with the model of inflation/output trade-off. In order for the results to be consistent with the model, we have to keep in mind that $\hat{\gamma}$ has to be significantly positive (and the residuals have to be non-serially correlated). Only eight countries out of the thirty-three considered seem consistent with the model. Moreover, the Breusch-Godfrey test shows that the null hypothesis of non-autocorrelation of residuals of the regressions for these eight countries is not rejected for conservative significance level (probabilities are over 1\%). The countries concerned are Argentina, Belarus, Guatemala, Guyana, Kyrgyzstan, Paraguay, Salvador and Turkmenistan. According to indicators of 
human development in table 2 , these countries are mostly characterized by medium human development, except for Belarus which is classified as a high human development country and Argentina which is in the very high human development category. There is no country characterized by low development in this panel. As for the nature of the organization of the political system (table 3), five countries are Western-style democracies and the other three are former popular democracies. There is no monarchy in the panel. None of these countries is located in Africa or in the Indian Ocean; only Belarus is a European country; others countries are located in America or in central Asia. Results of individual regressions for these eight countries are discussed below.

The estimated parameter $\hat{\gamma}$ exhibits noticeable variations from one country to another. It varies from 0.193 for Turkmenistan to 2.282 for Belarus. If $\hat{\gamma}=2$, it means that to keep the inflation rate $1 \%$ above the target, the Central Bank chair maintains the output gap at $0.5 \%$. And if $\hat{\gamma}$ is less than 2, which is the case for most of the eight countries, the Central Bank chair agrees to let the output gap vary even more. So the estimated values of $\hat{\gamma}$ are economically significant, proving the existence of an important trade-off between inflation and output.

The constant implicit inflation targets of Argentina, Belarus, Guatemala, Kyrgyzstan and Turkmenistan are of course significant, but above all, they are high, from $7.96 \%$ for Argentina to $36.95 \%$ for Belarus. And, for three other countries (Guyana, Paraguay and Salvador), the inflation trend is decreasing over the period, but starting from a high level of inflation.

Finally, it is tempting to comment the estimated values of $\phi$, but we have to keep in mind that the number of points in the sample characterized by $d_{t}=1$ is very low: 4 for Argentina, 4 for Belarus, 4 for Guatemala, 16 for Guyana, 4 for Kyrgyzstan, 2 for Paraguay, 7 for Salvador and 1 for Turkmenistan. So, we know that the standard error of the parameter is likely to be very high at an individual regression level. And effectively $\hat{\phi}$ is not significant in any of the 8 regressions except in the case of Salvador. Nevertheless, the parameter $\hat{\phi}$ is positive in seven out of eight cases, which may be indicative of the positivity of $\phi$. This positivity indicates that female Central Bank chairs would be more conservative than their male counterparts. The first step consists in testing the significance of a difference between female and male Central Bank chairs in the panel model (6). 
Table 7

Individual estimations of equation (5).

\begin{tabular}{|c|c|c|c|c|c|c|c|c|}
\hline Country & $\begin{array}{l}\text { Sample } \\
\text { period }\end{array}$ & $\hat{\bar{\pi}}$ & $\hat{\mathrm{a}}_{\pi}$ & $\hat{\mathrm{b}}_{\pi}$ & $\hat{\mathrm{c}}_{\pi}$ & $\hat{\gamma}$ & $\hat{\phi}$ & LM test \\
\hline \multirow[t]{3}{*}{ Argentina } & 1992-2014 & 7.960 & & & & 0.415 & -0.950 & 1.595 \\
\hline & & $(1.736)$ & & & & $(0.212)$ & (1.109) & 0.206 \\
\hline & & 0.000 & & & & 0.032 & 0.401 & \\
\hline \multirow[t]{3}{*}{ Austria } & 1981-1998 & 3.257 & & & & -0.652 & 0.060 & 2.629 \\
\hline & & $(0.249)$ & & & & (0.119) & (0.398) & 0.104 \\
\hline & & 0.000 & & & & 0.999 & 0.88 & \\
\hline \multirow[t]{3}{*}{ Bahamas } & 1981-2014 & & 8.148 & -0.491 & 0.009 & -0.064 & -0.118 & 4.216 \\
\hline & & & $(0.860)$ & (0.109) & $(0.002)$ & (0.039) & (0.109) & 0.040 \\
\hline & & & 0.000 & 0.000 & 0.003 & 0.940 & 0.284 & \\
\hline \multirow[t]{3}{*}{ Barbados } & 1981-2014 & 4.072 & & & & -0.275 & 0.048 & 3.532 \\
\hline & & $(0.555)$ & & & & $(0.141)$ & $(0.304)$ & 0.060 \\
\hline & & 0.000 & & & & 0.969 & 0.874 & \\
\hline \multirow[t]{3}{*}{ Belarus } & 1996-2014 & 36.954 & & & & 2.282 & -2.430 & 3.262 \\
\hline & & (7.367) & & & & $(0.983)$ & (1.917) & 0.070 \\
\hline & & 0.000 & & & & 0.016 & 0.223 & \\
\hline \multirow[t]{3}{*}{ Botswana } & 1981-2014 & & 11.134 & -0.067 & -0.001 & -0.132 & 0.174 & 3.497 \\
\hline & & & (1.299) & $(0.162)$ & $(0.004)$ & $(0.070)$ & $(0.180)$ & 0.061 \\
\hline & & & 0.000 & 0.680 & 0.650 & 0.9651 & 0.339 & \\
\hline \multirow[t]{3}{*}{ China } & 1987-2014 & 4.269 & & & & 0.084 & -3.661 & 12.83 \\
\hline & & (1.105) & & & & $(0.320)$ & (1.139) & 0.000 \\
\hline & & 0.000 & & & & 0.397 & 0.003 & \\
\hline \multirow[t]{3}{*}{ Denmark } & 1981-2014 & & 8.912 & -0.629 & 0.012 & -0.106 & -0.217 & 6.079 \\
\hline & & & $(0.897)$ & $(0.115)$ & $(0.002)$ & (0.089) & $(0.271)$ & 0.013 \\
\hline & & & 0.000 & 0.000 & 0.000 & 0.879 & 0.428 & \\
\hline \multirow[t]{3}{*}{ Ecuator } & 1981-2014 & & 18.858 & 2.641 & -0.099 & -0.600 & 4.005 & 8.723 \\
\hline & & & (7.843) & (1.032) & $(0.027)$ & $(0.782)$ & $(2.283)$ & 0.003 \\
\hline & & & 0.022 & 0.016 & 0.001 & 0.775 & 0.089 & \\
\hline \multirow[t]{3}{*}{ Finland } & 1981-2014 & & 10.627 & -0.798 & 0.016 & -0.115 & 0.028 & 5.383 \\
\hline & & & $(0.688)$ & (0.099) & $(0.002)$ & $(0.058)$ & (0.104) & 0.020 \\
\hline & & & 0.000 & 0.000 & 0.000 & 0.971 & 0.787 & \\
\hline Guatemala & 1981-2014 & 9.683 & & & & 0.765 & -0.183 & 4.053 \\
\hline & & (1.199) & & & & $(0.311)$ & (1.310) & 0.044 \\
\hline & & 0.000 & & & & 0.009 & 0.889 & \\
\hline Guyana & 1981-2014 & & 30.546 & -0.929 & 0.001 & 1.175 & -0.602 & 6.058 \\
\hline & & & (7.177) & $(0.962)$ & $(0.025)$ & $(0.244)$ & $(0.640)$ & 0.013 \\
\hline & & & 0.000 & 0.342 & 0.951 & 0.000 & 0.360 & \\
\hline Honduras & 1981-2014 & & 1.852 & 1.407 & -0.040 & -1.251 & 1.224 & 4.325 \\
\hline & & & (3.309) & $(0.410)$ & $(0.010)$ & (0.509) & $(0.680)$ & 0.037 \\
\hline & & & 0.580 & 0.001 & 0.000 & 0.989 & 0.082 & \\
\hline Kenya & 1981-2014 & 10.702 & & & & -0.546 & -2.140 & 8.061 \\
\hline & & (1.211) & & & & $(0.262)$ & (2.919) & 0.004 \\
\hline & & 0.000 & & & & 0.977 & 0.468 & \\
\hline Kyrgyzstan & 1995-2014 & 11.693 & & & & 1.427 & -2.267 & 0.359 \\
\hline & & (2.019) & & & & $(0.474)$ & (1.646) & 0.548 \\
\hline & & 0.000 & & & & 0.003 & 0.186 & \\
\hline Laos & 1981-2014 & 19.037 & & & & -1.868 & 0.238 & 2.699 \\
\hline & & (4.026) & & & & (1.698) & $(2.975)$ & 0.100 \\
\hline & & 0.000 & & & & 0.860 & 0.936 & \\
\hline Lesotho & 1981-2014 & & 14.478 & -0.260 & -0.001 & -0.086 & 0.081 & 1.332 \\
\hline & & & (1.653) & $(0.218)$ & $(0.006)$ & $(0.180)$ & $(0.822)$ & 0.248 \\
\hline & & & 0.000 & 0.244 & 0.871 & 0.681 & 0.921 & \\
\hline Malaysia & 1981-2014 & 2.933 & & & & -0.155 & -0.150 & 2.858 \\
\hline & & $(0.280)$ & & & & (0.049) & $(0.337)$ & 0.090 \\
\hline & & 0.000 & & & & 0.998 & 0.658 & \\
\hline Marshall & 2004-2014 & 3.479 & & & & -1.119 & 0.754 & 0.631 \\
\hline Islands & & (1.246) & & & & $(0.961)$ & (1.334) & 0.426 \\
\hline & & 0.023 & & & & 0.861 & 0.587 & \\
\hline Pakistan & 1981-2014 & 7.694 & & & & -0.598 & -0.514 & 3.308 \\
\hline & & $(0.473)$ & & & & $(0.178)$ & $(0.447)$ & 0.068 \\
\hline & & 0.000 & & & & 0.998 & 0.259 & \\
\hline Paraguay & 1990-2014 & & 62.767 & -4.139 & 0.073 & 0.283 & 0.424 & 0.654 \\
\hline & & & (8.977) & $(0.820)$ & $(0.017)$ & $(0.136)$ & $(0.391)$ & 0.418 \\
\hline & & & 0.000 & 0.000 & 0.000 & 0.025 & 0.291 & \\
\hline Poland & 1991-2014 & & 137.50 & -9.922 & 0.178 & 0.053 & -0.135 & 0.995 \\
\hline & & & $(23.47)$ & (2.130) & $(0.044)$ & $(0.329)$ & $(0.191)$ & 0.318 \\
\hline & & & 0.000 & 0.000 & 0.000 & 0.436 & 0.488 & \\
\hline Russia & 1993-2014 & & 635.20 & -45.57 & 0.808 & -1.723 & -3.733 & 0.459 \\
\hline & & & (79.11) & (6.788) & (0.139) & $(0.473)$ & $(2.566)$ & 0.498 \\
\hline & & & 0.000 & 0.000 & 0.000 & 0.999 & 0.163 & \\
\hline
\end{tabular}




\begin{tabular}{|c|c|c|c|c|c|c|c|c|}
\hline \multirow[t]{3}{*}{ Salvador } & \multicolumn{2}{|l|}{ 1981-2014 } & 22.342 & -1.004 & 0.010 & 0.541 & -0.806 & 0.038 \\
\hline & & & $(2.375)$ & $(0.298)$ & $(0.007)$ & $(0.102)$ & 0.395 & 0.844 \\
\hline & & & 0.000 & 0.002 & 0.177 & 0.000 & 0.050 & \\
\hline \multirow[t]{3}{*}{ Samoa } & $1981-2014$ & 4.642 & & & & -0.445 & -0.365 & 0.008 \\
\hline & & (1.621) & & & & $(0.264)$ & (1.068) & 0.926 \\
\hline & & 0.007 & & & & 0.949 & 0.734 & \\
\hline \multirow[t]{3}{*}{ Sao Tome } & 1981-2014 & & -1.009 & 3.390 & -0.093 & -0.465 & -3.638 & 9.323 \\
\hline & & & (6.418) & $(0.799)$ & $(0.020)$ & $(0.823)$ & $(2.035)$ & 0.002 \\
\hline & & & 0.876 & 0.000 & 0.000 & 0.712 & 0.084 & \\
\hline \multirow[t]{3}{*}{ Serbia } & 1999-2014 & & 323.16 & -20.37 & 0.326 & 0.349 & -2.075 & 0.208 \\
\hline & & & (127.7) & (9.493) & $(0.172)$ & $(0.664)$ & $(2.931)$ & 0.647 \\
\hline & & & 0.028 & 0.055 & 0.085 & 0.354 & 0.493 & \\
\hline \multirow[t]{3}{*}{ Seychelles } & 1981-2014 & 3.927 & & & & -0.228 & 0.519 & 1.399 \\
\hline & & (1.309) & & & & $(0.196)$ & (1.044) & 0.236 \\
\hline & & 0.005 & & & & 0.872 & 0.622 & \\
\hline \multirow[t]{3}{*}{ South Africa } & 1981-2014 & 8.941 & & & & -0.209 & -0.626 & 23.70 \\
\hline & & $(0.728)$ & & & & $(0.256)$ & (1.086) & 0.000 \\
\hline & & 0.000 & & & & 0.789 & 0.568 & \\
\hline \multirow[t]{3}{*}{ Tonga } & 1981-2014 & 6.549 & & & & -0.055 & 0.434 & 2.042 \\
\hline & & $(0.856)$ & & & & $(0.084)$ & $(0.334)$ & 0.153 \\
\hline & & 0.000 & & & & 0.741 & 0.202 & \\
\hline \multirow[t]{3}{*}{ Turkmenistan } & $1998-2014$ & 8.177 & & & & 0.193 & -0.394 & 0.217 \\
\hline & & (1.084) & & & & $(0.064)$ & $(0.379)$ & 0.641 \\
\hline & & 0.000 & & & & 0.004 & 0.316 & \\
\hline \multirow[t]{3}{*}{ Venezuela } & 1981-2014 & 25.664 & & & & -0.677 & -1.052 & 12.16 \\
\hline & & (2.499) & & & & $(0.358)$ & (1.375) & 0.000 \\
\hline & & 0.000 & & & & 0.966 & 0.450 & \\
\hline
\end{tabular}

Note: For every parameter, we present the estimated value, the standard error (into brackets) and the probability of the test of nullity of the estimated parameter, except for $\hat{\gamma}$, for which the probability is the one associated with the unilateral test of negativity. LM test refers to the Breusch-Godfrey serial correlation LM test; the first value is the statistics of the test and the second the probability of the null hypothesis of no autocorrelation of residuals.

\subsection{Panel regression}

According to the results of the previous section, we selected eight countries (Argentina, Belarus, Guatemala, Guyana, Kyrgyzstan, Paraguay, Salvador and Turkmenistan) to estimate the non-linear panel model (6). The model is estimated using a non-linear SUR method, which exploits the errors correlation of the different countries.

Table 8 presents the results relative to the country-specific estimated parameters $\left(\hat{\bar{\pi}}_{\mathrm{j}}, \hat{\mathrm{a}}_{\pi \mathrm{j}}, \hat{\mathrm{b}}_{\pi \mathrm{j}}, \hat{\mathrm{c}}_{\pi \mathrm{j}}\right.$ and $\left.\hat{\gamma}_{\mathrm{j}}\right)$ and table 9 presents the results of the common estimated parameter $\hat{\rho}$.

Table 8

Panel estimation of country-specific estimated parameters.

\begin{tabular}{|c|c|c|c|c|c|c|}
\hline Country & Sample period & $\hat{\bar{\pi}}$ & $\hat{\mathrm{a}}_{\pi}$ & $\hat{\mathrm{b}}_{\pi}$ & $\hat{\mathrm{c}}_{\pi}$ & $\hat{\gamma}$ \\
\hline Argentina & 1992-2014 & $\begin{array}{l}7.841 \\
(1.539) \\
0.000\end{array}$ & & & & $\begin{array}{l}0.323 \\
(0.197) \\
0.051\end{array}$ \\
\hline Belarus & 1996-2014 & $\begin{array}{l}39.337 \\
(6.596) \\
0.000\end{array}$ & & & & $\begin{array}{l}2.670 \\
(0.809) \\
0.000\end{array}$ \\
\hline Guatemala & 1981-2014 & $\begin{array}{l}9.841 \\
(1.064) \\
0.000\end{array}$ & & & & $\begin{array}{l}0.557 \\
(0.256) \\
0.015\end{array}$ \\
\hline Guyana & 1981-2014 & & $\begin{array}{l}26.300 \\
(5.525) \\
0.000\end{array}$ & $\begin{array}{l}-0.724 \\
(0.731) \\
0.323\end{array}$ & $\begin{array}{l}0.001 \\
(0.019) \\
0.926\end{array}$ & $\begin{array}{l}1.039 \\
(0.215) \\
0.000\end{array}$ \\
\hline Kyrgyzstan & 1995-2014 & $\begin{array}{l}12.204 \\
(1.809) \\
0.000\end{array}$ & & & & $\begin{array}{l}1.353 \\
(0.380) \\
0.000\end{array}$ \\
\hline Paraguay & $1990-2014$ & & $\begin{array}{l}51.652 \\
(7.056) \\
0.000\end{array}$ & $\begin{array}{l}-3.167 \\
(0.640) \\
0.000\end{array}$ & $\begin{array}{l}0.054 \\
(0.013) \\
0.000\end{array}$ & $\begin{array}{l}0.275 \\
(0.119) \\
0.015\end{array}$ \\
\hline
\end{tabular}




\begin{tabular}{|c|c|c|c|c|c|c|}
\hline Salvador & 1981-2014 & & $\begin{array}{l}19.939 \\
(1.640)\end{array}$ & $\begin{array}{l}-0.875 \\
(0.207)\end{array}$ & $\begin{array}{l}0.011 \\
(0.005)\end{array}$ & $\begin{array}{l}0.468 \\
(0.092)\end{array}$ \\
\hline Turkmenistan & 1998-2014 & $\begin{array}{l}8.647 \\
(0.968) \\
0.000\end{array}$ & 0.000 & 0.000 & 0.022 & $\begin{array}{l}0.000 \\
0.189 \\
(0.055) \\
0.000\end{array}$ \\
\hline
\end{tabular}

estimated parameter, except for $\hat{\gamma}$, for which the probability is the one associated with the unilateral test of negativity.

According to Table 8, panel estimation gives similar results to those of individual regressions. The restriction induced by the common parameter and the consideration of the error correlation does not seem to alter the results.

Table 9

Panel estimation of the common parameter $\rho$.

\begin{tabular}{ccc}
\hline$\hat{\rho}$ & Standard error of $\hat{\rho}$ & Probability (test of nullity of $\rho$ ) \\
-0.736 & 0.274 & 0.007 \\
\hline
\end{tabular}

Table 9 presents the main result of the paper: $\hat{\rho}$ is significantly different from zero, and it is negative, confirming the results of individual regressions, that female Central Bank chairs appear to put more emphasis on price stability than output stability in comparison to male Central Bank chairs. The estimated parameter $\hat{\rho}$ is even highly negative, the female Central Bank chairs being $73 \%$ less attached to the stabilization of output objective than men. Clearly, monetary policy appears to be less accommodative when conducted by female Central Bank chairs. This result of a larger degree of conservativeness associated with female Central Bank chairs is in line with previous analysis (see Bennani and al., 2015).

In fact, we can even wonder if female Central Bank chairs are interested in output stabilization, as $\hat{\rho}$ is close to -1 . We decided to test $\left\{\begin{array}{l}H_{0}: \rho \leq-1 \\ H_{1}: \rho>1\end{array}\right.$, which is more convenient than $\left\{\begin{array}{l}H_{0}: \rho=-1 \\ H_{1}: \rho \neq-1\end{array}\right.$ as $\rho$ can't be less than -1 , using the t-statistics $(\hat{\rho}+1) /$ stand. err. of $\hat{\rho}$. The value of the statistics is 0.936 , and the probability of a standard normal variable to be more than 0.936 is 0.175 , which is the probability of the test. Thus the hypothesis that female Central Bank chairs don't regard output stabilization, and are concerned only with inflation stabilization, cannot be rejected for a significance level of $10 \%$, which assesses the importance of gender in central banking. 


\section{Conclusion}

Comparatively to the corporate boards, the gender of the Central Bank's chair has not so far been a subject of academic work. The contribution of this study to the literature on gender and monetary policy is to provide a deep insight of the female's under-representation among Central Bank chairs over the world, and to describe the way they resolve the inflation/output trade-off relatively to their male counterparts. To this aim, we have built a unique data set compiling information about female Central bank chairs since 1949. Our sample is larger and more recent than previous studies, and its originality lies in the fact that we included developed and emerging countries. Of course, there are other available data sets but they are incomplete or display some errors (misunderstandings about persons, confusions between Central Banks and national commercial banks).

From the data compiled, we identified 56 female Central Bank chairs, i.e. a very small minority. By using various international data about socio-economic indicators (level of human development, gender gaps) and socio-political characteristics (religion, traditions, political representation, political organization, geographical location), we found that: the female Central Bank chairs appointment was not influenced by the countries' level of human development; female under-representation, as Central Bank chairs, seems to result from tradition, religion and to the inequality gap with men, which is globally prevalent in societies.

As long as Central Banks were totally dependent of politics, roughly before the 1990s, the governments showed a clear inclination to appoint male Central Bank chairs. Since the beginning of the 1990s, Central Banks have become more independent and empowered to focus on the price stability goal, and governments started to appoint, more frequently, female Central Bank chairs, albeit always in a low proportion. Perhaps this is entirely due to the fact that the international movement of institutional monetary reforms coincided with a social change for women. Another explanation may simply result from female preferences on monetary policy goals in comparison with men. Indeed, while Central Banks were given independence, women selected to chair Central Banks have a career and an academic background consistent with a preference for the price stability, which leads us to think that the appointment of women may have been the result of a political will.

As only an empirical analysis can establish how female and male Central Bank chairs differ in the conduct of monetary policy, we examined if policy preferences are influenced by gender. We developed an innovative methodology, based on an idea first coined by Diouf and 
Pépin (2010), which does not require estimating all the structural and preference parameters of a monetary model, but only how men and women's parameters differ.

As a preliminary, the empirical analysis of the inflation/output trade-off reveals that, among the 33 countries in the sample, only eight appear to be consistent with a model of inflation targeting (Argentina, Belarus, Guatemala, Guyana, Kyrgyzstan, Paraguay, Salvador and Turkmenistan). Preferences cannot be inferred from the other twenty-four countries, as the implemented monetary policy in these countries does not seem to result from a compromise between stabilization of inflation and output growth. A panel data analysis conducted on the eight countries, whose monetary policy is consistent with inflation targeting, shows that female Central Bank chairs put more emphasis on stabilization of inflation comparatively to their male counterparts. Such a result is in line with previous studies on a larger degree of hawkishness from female. This is explained by the fact that female policymakers for monetary policy need to be more conservative, in their preference, in order to acquire/reinforce a reputation (Wilson, 2014; Farvaque et al., 2015). They are $73 \%$ less attached to the objective of output stabilization than men, which reveals they have a high degree of aversion to inflation i.e. they are conservative in the sense of Rogoff (1985). Actually, female Central Bank chairs appear so hawk according to our results we cannot even reject the hypothesis that they are only concerned with inflation stabilization. This strong conservatism may be a factor explaining their appointment to the Central Bank chair, as the central banker's conservatism has been advocated, on the basis of Rogoff's work, as a way to gain in credibility and reputation. To some extent, this attachment to the ultimate monetary policy goal, reflected by a high degree of conservatism, can be interpreted as a sign of a greater ability to resist political pressures, and hence of independence in the conduct of monetary policy.

Nevertheless, we have to be cautious with the interpretation of these empirical results, because they are based on the empirical analysis of only eight countries which are mostly in the medium human development category. It will be interesting to repeat the estimation conducted in this paper within a few years, when more data about countries in the very high human development category are available.

\section{References}

Acheson, Keith, and John F. Chant, 1973. Bureaucratic Theory and the Choice of Central Bank Goals: The Case of The Bank of Canada, Journal of Money, Credit and Banking. 5(2): 637-655.

Alesina, Alberto, and Paola Giuliano, 2013. Culture and Institutions, NBER Working Paper. No. 19750. 
Barro, Robert J. and Rachel M. McCleary, 2003. Religion and Economic Growth across Countries, American Sociological Review. 68(5): 760-781.

Bennani, Hamza, Etienne Farvaque, and Piotr Stanek, 2015. FOMC members' incentives to disagree: regional motives and background influences, Narodowy Bank Polski Working Paper No. 221.

Castelnuovo, Efrem, and Paolo Surico, 2003. What Does Monetary Policy Reveal about a Central Bank's Preferences?, Economic Notes. 32(3): 335-359.

Cecchetti, Stephen G., and Michael Ehrmann, 2002. Does inflation Targeting Increase Output Volatility? An International Comparison of Policymakers Preferences and Outcomes, in: Loayza N. and K. Schmidt-Hebbel (eds.), Monetary Policy: Rules and Transmission Mechanisms. Santiago: Central Bank of Chile: 247-274.

Chang, Kelly H., 2006. Appointing Central Bankers: The Politics of Monetary Policy in the United States and the European Monetary Union. Cambridge: Cambridge University Press.

Chappell, Henry W., and Rob Roy McGregor, 2000. A long history of FOMC voting behavior, Southern Economic Journal. 66(4): 906-922.

Chappell, Henry W., Rob Roy McGregor and Todd Vermilyea, 2005. Committee Decisions on Monetary Policy: Evidence from Historical records of the Federal Open Market Committee. Cambridge: MIT Press.

Clarida, Richard, Jordi Galí, and Mark Gertler, 1999. The Science of Monetary Policy: A New Keynesian Perspective, Journal of Economic Literature. 37: 1661-1707.

Cox-Fill, Olivia, 1996. For Our Daughters: How Outstanding Women Worldwide Have Balanced Home and Career. Us: Praeger.

Dennis, Richard, 2006. The Policy Preferences of the US Federal Reserve, Journal of Applied Econometrics. 21: 55-77.

Diouf, Ibrahima, and Dominique Pépin, 2010. Duisenberg and Trichet: Measures of their Degree of Conservatism, Louvain Economic Review. 76(2): 145-162.

Eijffinger, Sylvester C., Ronald Mahieu, and Louis Raes, 2015. Hawks and Doves in the FOMC, CEPR Discussion Paper Series. 10442.

Epstein, Gerald A. and A. Erinç Yeldan, 2010. Beyond Inflation Targeting: Assessing the Impacts and Policy Alternatives. Us: Edward Elgar.

Farvaque, Etienne, and Alexander Mihailov, 2009. Intergenerational Transmission of Inflation Aversion: Theory and Evidence, IRISS Working Paper. CEPS/INSTEAD.

Farvaque, Etienne, Hakim Hammadou, and Piotr Stanek, 2011. Selecting Your Inflation Targeters: Background and Performance of Monetary Policy Committee Members, German Economic Review. 12: 223-238.

Farvaque Etienne, Piotr Stanek and Stéphane Vigeant, 2014. On the Performance of Monetary Policy Committees, Kyklos. 67(2): 177-203.

Favero, Carlo A., and Riccardo Rovelli, 2003. Macroeconomic Stability and the Preferences of the Fed: A formal Analysis, 1961-98, Journal of Money Credit and Banking. 35(4): 545-556.

Galbraith, John Kenneth, 1977. The Age of Uncertainty. Paris: Gallimard.

Gergen, David, 2013. A Horrible Way to Fill the Second Most Powerful Job in America, CNN. September 17.

Hale, Galina, and Tali Regev, 2001. Sex Ratios at Top PhD Programs in Economics, Federal Reserve Bank of San Francisco. 9(7): 1-29.

Hix, Simon, Bjørn Høyland, and Nick Vivyan, 2010. From doves to hawks: A spatial analysis of voting in the Monetary Policy Committee of the Bank of England, European Journal of Political Research. 49(6), 731758.

Jones, Claire, 2013. Six Things you Need to Know about Women in Central Banking, Financial Times. October 9.

Krause, Stefan, and Fabio Méndez, 2008. Institutions, Arrangements and Preferences for Inflation Stability: Evidence and Lessons from a Panel Data Analysis, Journal of Macroeconomics. 30: 282-307.

Krause, Stefan, and Fabio Méndez, 2005. Policy Makers' Preferences, Party Ideology, and the Political Business Cycle, Southern Economic Journal. 71(4): 752-767.

Masciandaro, Donato, Paola Profeta, Davide Romelli, 2016. Gender and Monetary Policymaking: Trends, Drivers and Effects, BAFFI CAREFIN Centre Research Paper Series. 2015-12.

Mishkin, Frederic S., 2007. Monetary Policy and the Dual Mandate, Speech given at Bridgewater College. Virgina.

Ozlale, Umit, 2003. Price Stability vs. Output Stability: Tales of Federal Reserve Administrations, Journal of Economic Dynamics and Control. 27: 1595-1610.

Perlberg, Steven, 2013. OBAMA: Both Yellen and Summers are 'Outstanding Candidates' For Fed Chair, Business Insider. August 9.

Riboni, Alessandro, Francisco J. Ruge-Murcia, 2008. Preference Heterogeneity in Monetary Policy Committee, International Journal of Central Banking. 4(1): 213-33. 
Rogoff, Kenneth, 1985. The Optimal Degree of Commitment to an Intermediate Monetary Target, Quarterly Journal of Economics. 100(4): 1169-89.

Scheve, Kenneth F., 2004. Public Inflation Aversion and the Political Economy of Macroeconomic Policymaking, International Organization. 58(1): 1-34.

Svensson, Lars E.O., 1997. Inflation Forecast Targeting: Implementing and Monitoring Inflation Targets, European Economic Review. 41: 1111-1147.

Svensson, Lars E.O., 1999. Inflation Targeting as a Monetary Policy Rule, Journal of Monetary Economics. 43(3): 607-654.

Tachibana, Minoru, 2004. Central Banks' Preferences in Japan, the UK, and the US, Japan and the World Economy. 16: 81-93.

Toma, Eugenia Froedge, and Mark Toma, 1986. Central Bankers, Bureaucratic Incentives, and Monetary Policy. The Netherlands: Dordrecht.

Wilson, Linus, 2014. A Dove to Hawk Ranking of the Martin to Yellen Federal Reserves, Unpublished Working Paper. Department of Finance, University of Lousiana at Lafayette. 